\title{
The Effect of Implementing MALL Applications on Learning Pronunciation of English by EFL Learners at Najran University
}

\author{
Mariam Yousef Mohammed Abduh \\ English Department, Faculty of Languages \\ Najran University, KSA \\ $\&$ \\ English Department, Faculty of Education \\ Hodeidah University, Yemen \\ E-mail: mariamabduh@yahoo.com
}

Received: October 21, 2019 Accepted: November 11, 2019 Published: November 13, 2019 doi:10.5296/ijl.v11i6.15814

URL: https://doi.org/10.5296/ijl.v11i6.15814

\begin{abstract}
Currently, the advancement in technology and communication has significantly influenced the field of education. As a part of this development, the use of mobile phones is being considered as a substantial source of learning for EFL learners. This study was conducted to investigate the effect of mobile phones on students' pronunciation skill. The participants in this study were 48 female native speakers of Arabic enrolled in the English Department at Najran University, Saudi Arabia. They were divided into two groups; namely the control group (learning without mobile phones) and the experiment group (learning with mobile phones) with 24 students for each group. The obtained data were analyzed using t-test and it showed that the posttest performance development mean and standard deviation of the participants in the experiment group equaled 23.333, and 6.58501, respectively. However, the computed posttest performance development mean and standard deviation of the participants in the control group equaled 17.9167, and 6.37193, respectively, which indicates that there is a significant difference between the experiment group and the control group in terms of overall performance. So, it can be concluded that the results approved the significant impact of using MALL technology in improving the pronunciation of EFL learners.
\end{abstract}




\section{Mll Macrothink}

International Journal of Linguistics

ISSN 1948-5425

2019, Vol. 11, No. 6

Keywords: Mobile-Assisted Language Learning (MALL), Mobile phones, Pretest, Posttest experiment, Control, CALL (Computer Assisted Language Learning), Pronunciation, Foreign language

\section{Introduction}

\subsection{Research Problem and Significance}

Nowadays, there has been an increasing interest in the integration of technology in language teaching and learning. The use of stereotyped traditional teaching methods has become unpopular, while multimedia technology provides more access to information beside a sense of reality and functions which greatly encourages students to learn more, motivates them in study and get them involved effectively in class activities. The development of technology has resulted in many technological devices which can be useful in the field of education, such as mobile phones, laptops, iPads, etc. As a result, many universities, colleges and other educational institutes all around the world have started giving their training program via the internet, which is referred to as e-learning. In the literature, mobile-assisted language learning (MALL) has been investigated by many studies and the results indicated that applications of mobile phones are useful to foster language learning. However, most of the previous studies have focused on the effect of MALL on reading skills, writing, grammar, and vocabulary learning. Very few studies have examined the effect of MALL on pronunciation.

\subsection{Research Objectives}

The current study was conducted to examine the effect of mobile phone applications on pronunciation of English and to explore which aspect of pronunciation is more difficult to Arab learners of English.

\subsection{Research Questions}

This study tried to find justifiable answers to the following questions:

1) Will the use of MALL applications lead to significantly better results in pronunciation than traditional class room techniques?

2) Will the use of MALL applications enhance the learning of English pronunciation and stress patterns of EFL learners?

3. What kinds of pronunciation problems EFL learners may face in English?

\section{Literature Review}

\subsection{Mobile-Assisted Language Learning}

Mobile phones are useful tools for language learning. Extensive access to such inexpensive and sophisticated devices has completely changed the field of language learning and teaching. However using mobile phones in ELT does not mean that these devices have replaced the existing teaching and learning tools. In fact, they help facilitate the learning process and make it more interesting as they are characterized by their potentiality for learning and teaching. Besides, mobile leaning is an unstructured, informal, and personalized process. Mobile 
phones can provide exciting, engaging and motivating learning activities. Learners can connect with their peers through mobile devices to complete learning activities (Palalas, 2011) Using apps, particularly, provides student with choice in the sense that students can decide for themselves certain apps to develop their language skills. This is critically significant since choice is an important part of self-directed learning.

Kim, H., \& Kwon, Y. (2012) identify the benefits of MALL as follows:

"First, MALL enables students to more easily and more promptly access language learning materials and communicate with people at any time, from anywhere. Second, the nature of digital technology facilitates students' participation in both collaborative and individualized language learning activities synchronously and/or asynchronously allowing rapid development of speaking, listening, reading, and writing, skills. Third, mobile technology provides various resources and tools for language learning that encourage learners to be more motivated, autonomous, situated (site-specific), and socially interactive."

(MALL) has been investigated by many studies and the results indicated that applications of mobile phones are useful to foster language learning. In many studies, MALL was employed and positive results were reported on its efficacy (Alavinia \& Qoitassi, 2013; Chen, Hsieh, \& Kinshuk, 2008; Motallebzadeh \& Ganjali, 2011; Yang, 2013). Besides, the skill area of the choice seems to be vocabulary acquisition (Duman, Orhon, \& Gedik, 2015; H.-S. Kim, 2011; H. Kim \& Kwon, 2012).

Mobile phones are considered as a significant instance of universal learning devices, and they play now a crucial part of peoples' life. This is due to their being moveable, socially interactive, context-sensitive, connective and individual to language learners (Klopfer, Squire, $\&$ Jenkins, 2002). The advent of mobile devices has influenced the life of millions of people around the world. This rise of technology from lap to palm has literally given a potential language-learning tool in the hands of the teachers and their students (Kukulska-Hulme, 2009). Currently, there are more than 7 billion mobile devices subscriptions worldwide. Mobile devices are integrated into education as a tool to facilitate language learning and they are used in many ways. Researchers have noted that mobile-assisted language learning (MALL) provides students with rich, real-time, convenient, and contextual learning opportunities, no matter whether they are inside or outside the classroom (Kukulska-Hulme, \& Shield, 2008). In addition, insights from CALL (Computer Assisted Language Learning) can be used to inform the learning activities presented through mobile phones (Kukulska-Hulme, 2005).

In the literature, many studies focused on incidental vocabulary learning using mobile devices (e.g. Fisher et al., 2009; Song \& Fox, 2008). Some other studies focused on instructed vocabulary learning through mobile devices (e.g. Lu, 2008; Thornton \& Houser, 2005). Başoğlu and Akdemir (2010) investigated the impact of an online vocabulary learning and flashcards on vocabulary learning. In this study, sixty Turkish EFL students participated and the result indicated that learners using mobile phones outperformed others and they were 
more motivated. Burston (2012, p.16) concluded that "the learning outcomes of MALL implementations are unquestionable positive in nearly $80 \%$ of the cases".

Several studies were conducted to find out the effectiveness of mobile devices on language learning, Moreover, completing learning tasks collaboratively using mobile phones was found effective (Lan, Sung, \& Chang, 2007; Lim Abdullah, Hussin, Asra, \& Zakaria, 2013).

From the viewpoint of transactional distance, mobile phones have, also, an advantage. MALL fits well into PPP (Presentation, practice and production paradigm). Mobile phones can present rich learning material in multimodal ways (H. Jarvis, 2015; Mayer, 2003). Evaluation of six pilot projects in developing countries (Valk, Rashid, \& Elder, 2010) concluded that mobile phones have the potential to impart instruction. They have the potential to help create an environment that is conducive to a variety of learning scenarios such as formal and informal learning (Lung-Hsiang Wong, 2012). Hence, all previous studies carried out so far have found that using mobile devices in language learning and teaching is beneficial to EFL learners.

\section{Research Methodology}

The previous studies have examined how MALL is effective for learning a language. This study has been designed to explore the hypothesis that mobile applications have a positive effect on the development of foreign language pronunciation. To examine this hypothesis, an experimental study was conducted. This study followed a mixed-methods approach, using a pre/posttest research design. The study was carried out for one semester in the academic year 2018/2019 at Najran University, Saudi Arabia.

\subsection{Participants}

The participants in this study were 48 female native speakers of Arabic enrolled in the English Department at Najran University, Saudi Arabia.

\subsection{Study Design}

This study followed a mixed-methods approach. It employed a between-subjects design in which participants learnt specific aspects of phonology under one of two conditions. The first groups were taught some phonological aspects using mobile applications. The second group were taught the same phonological aspects but in a traditional way. Therefore, the independent variable was the mobile applications, and the dependent variables were pronunciation with different aspects (e.g. word stress and consonant cluster). The dependent variables were measured by the pronunciation test. The test was administered prior to the intervention (i.e., pretest), and immediately after the intervention (i.e., posttest).

\subsection{Pronunciation Test}

The students were examined using an identical pronunciation test two times to see how improvements occurred over time. The test was developed based on Smith's (2001) arguments that Arab learners of English may face problems when pronouncing English due to the different phonetic systems between Arabic and English. One of these problems is that 
some sounds in English are considered allophonic in Arabic. For example, /I/ and /e/, and /p/ and $/ \mathrm{b} /$. Also, initial consonant clusters are not allowed in Arabic. Consonant clusters can occur in Arabic in the coda position, i.e. at the end of a syllable only but not more than two consonants. Omer, 1997, p. 301) points out that the structure of syllable in Arabic can be one of the three types: CV, CVC, and CVCC. Therefore, all the words included in the pronunciation tests, which consisted of 50 words for a total of 50 points, contained these problems.

\subsection{Procedure}

The study procedures consisted of four steps. The steps were as follows:

Step 1: Pre-test: Prior to the treatment, the participants in the two groups completed a pronunciation pre-test in which 50 polysyllabic words were provided. Their responses were recorded in a file to be analyzed later on by a panel of instructors to see how well they pronounced these items.

Step 2: Orientation and demonstration: Before the intervention, participants were shown how to pronounce words which contain consonant clusters. Also they were taught how to pronounce words with correct word stress, words containing problematic sounds such as: /I/, /e/, /p/, /b/, /v/ and words with consonant clusters.

Step 3: Intervention: Participants were divided into two groups, experimental and control. Each group was taught (pronouncing polysyllabic words with consonant clusters, and words consisting difficult sounds for Arab learners). The same content was taught but the environments will be different. The first one was taught with the help of mobile apps, while the second one was taught in a traditional way.

Step 4: post-test: After the experiment, participants took the same pronunciation test that had already been administered prior to the treatments. They were asked to read aloud the items given in the test and their performance were recorded by using their mobile phones. Every participant read aloud the items and she herself recorded them. The recordings were sent to the instructor via Whatsapp immediately after the treatments.

\section{Data Analysis}

The quantitative analysis of the collected data was made with the aid of SPSS software. The data obtained from 48 participants of the study were analyzed using descriptive statistics, paired-samples t-test, and independent samples t-test. The standard of $\mathrm{p}<.05$ was used in order to depict the significance throughout the study.

\subsection{Performance of the Experiment and Control Groups in the Pre-test}

Descriptive statistics and independent samples t-test were run to analyze the data gathered from pre-test of the experiment and control groups. The results of the pre-test performance of the participants are shown in Table1 and 2.

As it could be seen in Table 1, the mean scores of the experiment group and the control group are 8.0000 and 7.5000 respectively. As shown in the table, the mean difference size is small 
among the two groups which indicates that both groups are homogenous and there are no statistically significant differences between the control and experimental groups in their performance of the pretest.

Table 1. Paired samples statistics

\begin{tabular}{|c|c|c|c|c|c|}
\hline & & Mean & $\mathrm{N}$ & Std. Deviation & Std. Error Mean \\
\hline \multirow[t]{2}{*}{ Pair 1} & preexperim & 8.0000 & 24 & 2.18692 & .44640 \\
\hline & precontrol & 7.5000 & 24 & 1.79371 & .36614 \\
\hline
\end{tabular}

Table 2. Paired samples test- pretest

\begin{tabular}{|c|c|c|c|c|c|c|c|c|}
\hline & & \multicolumn{5}{|c|}{ Paired Differences } & \multirow{3}{*}{$\begin{array}{l}\text { e } \\
\text { e }\end{array}$} & \multirow{3}{*}{$\begin{array}{l}\text { Sig. } \\
\text { (2-tailed) }\end{array}$} \\
\hline & & \multirow[b]{2}{*}{ Mean } & \multirow{2}{*}{$\begin{array}{l}\text { Std. } \\
\text { Deviatior }\end{array}$} & \multirow{2}{*}{$\begin{array}{l}\text { Std. } \\
\text { Error } \\
\text { Mean }\end{array}$} & \multicolumn{2}{|c|}{$\begin{array}{l}95 \% \text { Confidence } \\
\text { Interval of the } \\
\text { Difference }\end{array}$} & & \\
\hline & & & & & Lower & Upper & & \\
\hline Pair 1 & $\begin{array}{l}\text { Pre experimer } \\
\text {-pre control }\end{array}$ & t. 50000 & 2.24577 & .45842 & $2-.44831$ & 1.44831 & 1.09123 & .287 \\
\hline
\end{tabular}

\subsection{Performance of the Experiment and Control Groups in the Posttest}

The results obtained from the post-test are presented in Table 3 and Table 4. The computed posttest performance development mean and standard deviation of the participants in the experiment group equaled 23.333, and 6.58501, respectively. However, the computed posttest performance development mean and standard deviation of the participants in the control group equaled 17.9167, and 6.37193, respectively. An inspection of the mean scores showed that there was a considerable difference between the experiment group and the control group in terms of overall performance. Comparing the results of the two groups in the posttest descriptively; the mean of experimental group $=23.333$, and the mean of control group $=$ 17.9167, it was concluded that the experimental group has improved in learning of pronunciation, consonant clusters and stress patterns than control group. Finally, comparing $\mathrm{T}$ values, obtained, $\mathrm{T}$ was less than critical $\mathrm{T}$, therefore, it can be surely said that there were statistically significant differences between the experiment and control groups on the posttest and we can conclude by saying that the results approved the significant impact of using MAII technology on improving the pronunciation of EFL learners. 
Table 3. Paired samples statistics - post test

\begin{tabular}{|c|c|c|c|c|c|}
\hline & & Mean & $\mathrm{N}$ & Std. Deviation & Std. Error Mean \\
\hline \multirow[t]{2}{*}{ Pair 1} & $\begin{array}{l}\text { Post-test } \\
\text { experimental }\end{array}$ & 23.3333 & 24 & 6.58501 & 1.34416 \\
\hline & $\begin{array}{l}\text { Post-test } \\
\text { control }\end{array}$ & 17.9167 & 24 & 6.37193 & 1.30066 \\
\hline
\end{tabular}

Table 4. Paired samples test

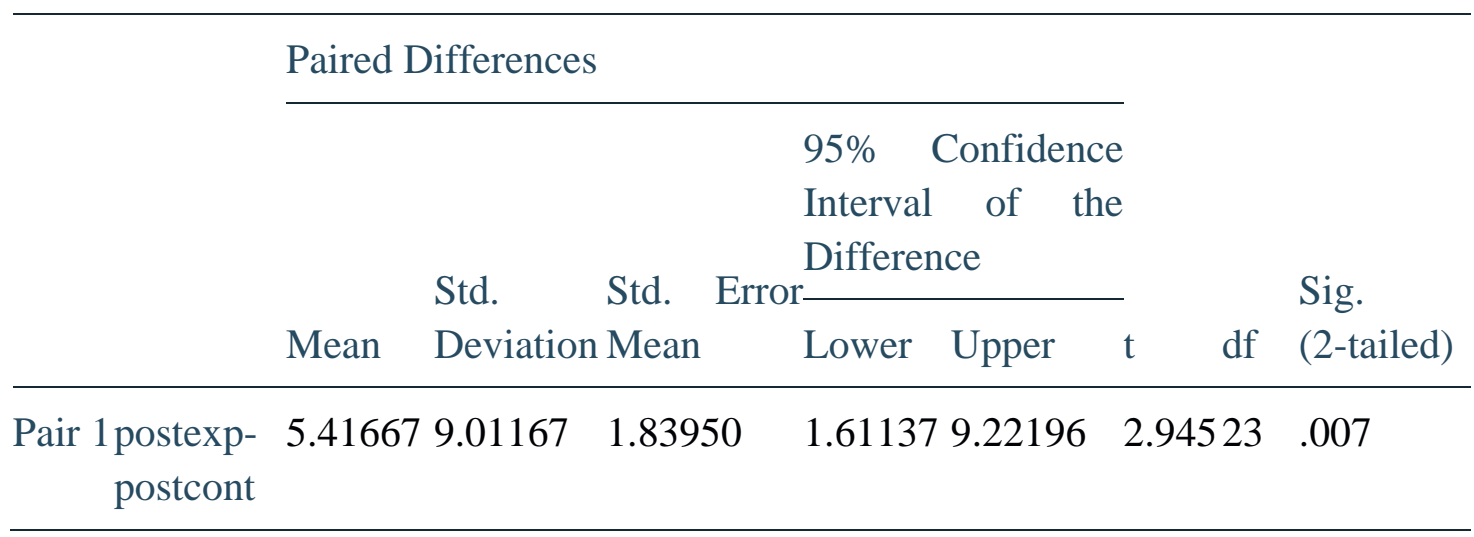

Table 5. Paired samples statistics

\begin{tabular}{llllll}
\hline & & Mean & $\mathrm{N}$ & Std. Deviation & Std. Error Mean \\
\hline Pair 1 & preexp & 8.6667 & 24 & 2.94392 & .60093 \\
\cline { 2 - 6 } & postexp & 23.3333 & 24 & 6.58501 & 1.34416 \\
\hline Pair 2 & precon & 7.0000 & 24 & 2.22632 & .45445 \\
\cline { 2 - 6 } & postcont & 17.9167 & 24 & 6.37193 & 1.30066 \\
\hline
\end{tabular}

Table 6. Paired samples test






\section{MInstitute"}

International Journal of Linguistics

ISSN 1948-5425

2019, Vol. 11, No. 6

\section{Pronunciation Difficulties Encountered by the Arab EFL Learners in the Study}

Al-Hattaami, (2000) claims that the phonological differences between Arabic and English systems are 'likely to create problems of pronunciation to native speakers of Arabic learning English as a foreign language'. Five English phonemes; /p/, /v/, /z/, /y/ and /r/ might be mispronounced by Arab learners of English as such sounds have no near/similar phonemes in the Arabic phonology. Altamimi (2015: 2) found that Arab learners of English substituted these phonemes (/p/, /3/, /v/, /t $/$ / and /y/) by (/b/, /dz/, /f/, /f/ and/n-k) respectively. Therefore, one may hear words like: /ben/ for / pen/, /fæn/ for /væn/and/ pledzər/ for / plezər/

/ arld/ for /t $\int a r l d / . C o n s e q u e n t l y$, most participants faced problems while pronouncing the phonemes above in the pretest phase whereas most vowels of English were mispronounced and replaced by others as shown in the table below:

Table 7. Most common errors in pronunciation produced in the pretest

\begin{tabular}{|c|c|}
\hline /I/ & Replaced by/e/ \\
\hline /e/ & Replaced by / I/ \\
\hline$/ \mathrm{p} /$ & Replaced by / / \\
\hline /o:/ & Replaced by /u:/ \\
\hline $\mid \alpha$ & Replaced by /a/ \\
\hline /3:/ & Replaced by /e/ \\
\hline$/ \mho /$ & Replaced by $\mathfrak{p}$ \\
\hline /a:/ & Replaced by $\mathfrak{x}$ \\
\hline /Іә/ & Replaced by /i:/ \\
\hline /రə/ & Replaced by/u:/ \\
\hline /eə/ & Replaced by/e:/ \\
\hline /əठ/ & Replaced by /っ:/ \\
\hline
\end{tabular}

A consonant cluster is defined as the "combination of more than one consonant occurring together within a single syllable" (Verma, 2014: 289). Regarding the pronunciation of consonant cluster of English, the results of this study demonstrate that EFL learners insert a vowel sound unintentionally in the onset as well as in the coda of certain English syllables due to mother tongue influence. Usually, the short vowel / I / is inserted before the cluster in word initial position as in 'strange' /streIndz/, which is pronounced as /Istremdz/.

Word stress is defined as "the emphasis we give to individual syllables within a word as well as the emphasis given to words within utterances" (Nunan, 2015: 96). Gilbert (2008: 14) relates the problem of EFL learners' inability to identify stressed words correctly to their unawareness 
of the stress patterns when they learn new words. Moreover, Shormani and Alsohbani (2015), found that stress patterns are one of the major obstacles that Arab learners of English face. They related this sort of difficulty to the consistent placements of stress in the Arabic language while English stress changed according to the words grammatical class (p.148). Thus, most participants faced serious problems in marking stress on disyllabic and multisyllabic words during the period of the study.

\section{Limitation of the Study}

Due to the fact that female and male learners were taught separately in Saudi universities, the present experimental study was confined to female EFL learners since gender was not considered a variable in this study.

\section{Conclusion}

It seems that Mobile Assisted Language Learning (MALL) has become an effective assisting tool in the process of language learning. Using technology as a means to help in the teaching /learning process has become inevitable. The present meta-analysis was conducted to synthesize the lesson learnt so far in the field of MALL. The findings of this study confirm the efficacy of MALL in EFL instruction, which supports the hypothesis posed in the research that mobile applications have a positive effect on the development of foreign language pronunciation.

Since MALL applications had a positive influence on improving EFL pronunciation as concluded above, this study was significant for highlighting the necessity of implementing this strategy in the absence of native English-speaking teachers. Furthermore, it exposed the type of pronunciation errors produced by EFL learners in Najran University and determined the need for improving and updating the strategies followed for learning/teaching English pronunciation.

\section{Suggestions for Further Studies}

A wide range of technologies and software have been designed specifically for teaching/learning pronunciation such as MALL applications. However, educational researches that investigate the use of these applications in teaching and learning pronunciation are insufficient. Thus, it is highly recommended that the current study may be expanded to investigate the negative effects of Arabic on pronouncing English sounds, particularly vowels. Also, some exercises/drills may be recommended in order to overcome problems and difficulties encountered. It would be, also, helpful to study the actual strategies and techniques followed in teaching pronunciation in EFL contexts.

Although the results of this study are broadly positive supporting previous studies, there is an area worth investigating further. Due to the fact that female and male learners in Saudi universities are taught separately, the current study was applied to Saudi female learners. However, it is reasonable to suggest a further study investigating the impact of implementing MALL applications on learning pronunciation in the male section and contrast it to the results of the study from the female section. 


\section{Macrothink}

International Journal of Linguistics

ISSN 1948-5425

2019, Vol. 11, No. 6

\section{References}

Alavinia, P., \& Qoitassi, K. (2013). On the viability of vocabulary learning enhancement through the implementation of MALL: The case of Iranian EFL learners. Journal of Language Teaching and Research, 4(2), 412-426. https://doi.org/10.4304/jltr.4.2.412-426

Al-Hattaami, A., \& A., D. (2000). A Phonetic and Phonological Study of the Consonants of English and Arabic. $M$ Ed Thesis (Unpublished Work). Hodeidah University. Yemen: Hodeidah.

Altamimi, Al. K. (2015). Improving English Pronunciation among Arabic EFL School-Age Student Using Minimal Pairs. Unpublished M.A. thesis, State University of New York.

Başoğlu, E., \& Akdemir, O. (2010). A comparison of undergraduate students' English vocabulary learning: Using cell phones and flash cards. The Turkish Online Journal of Educational Technology, 9(3), 1-7.

Burston, J. (2012). Mobile language learning: Getting IT to work. In J. Burston, F. Doa, \& D. Tsagari (Eds.), Foreign language instructional technology (pp. 81-99). Nicosia: University of Nicosia Press.

Chen, N.-S., Hsieh, S.-W., \& Kinshuk, A. (2008). Effects of short-term memory and content representation type on mobile language learning. Language Learning \& Technology, 12(3), 93-113.

Chickering, A. W., \& Ehrmann, S. C. (1996). Implementing the seven principles: Technology as lever. AAHE Bulletin, 49, 3-6.

Duman, G., Orhon, G., \& Gedik, N. (2015). Research trends in mobile assisted language learning from 2000 to 2012. ReCALL, 27(2), 197-216. https://doi.org/10.1017/S0958344014000287

Fisher, T., Pemberton, R., Sharples, M., Ogata, H., Uosaki, N., Edmonds, P., Hull, A., \& Tschorn, P. (2009). Mobile learning of vocabulary from reading novels: A comparison of three modes. In D. Metcalf, Hamilton, \& C. Graffeo (Eds.), Proceedings of 8th World Conference on Mobile and Contextual Learning (pp. 191-194). Orlando, FL: University of Central Florida

Gilbert, J. B. (2008). Teaching Pronunciation: Using the Prosody Pyramid. New York: Cambridge University Press. Retrieved from www.cambridge.org

Jarvis, H. (2015). From PPP and CALL/MALL to a praxis of task-based teaching and mobile assisted language use. Teaching English as a Second or Foreign Language Electronic Journal, 19(1), 1-10.

Kim, H., \& Kwon, Y. (2012). Exploring smartphone applications for effective mobile-assisted language learning. Multimedia-Assisted Language Learning, 15(1), 31-57.

Kim, H.-S. (2011). Effects of SMS text messaging on vocabulary learning. Multimedia Assisted Language Learning, 14(2), 159-180. 
Klopfer, E., Squire, K., \& Jenkins, H. (2002). Environmental detectives: PDAs as a window into a virtual simulated world. In Proceedings of IEEE International Workshop on Wireless and Mobile Technologies in Education (pp. 95-98). Vaxjo, Sweden: IEEE Computer Society.

Kukulska-Hulme, A. (2005). Mobile learning: A handbook for educators and trainers. New York: Routledge.

Kukulska-Hulme, A. (2009). Will mobile learning change language learning? ReCALL, 21(2), 157-165. https://doi.org/10.1017/S0958344009000202

Kukulska-Hulme, A., \& Shield, L. (2008). An overview of mobile assisted language learning: From content delivery to supported collaboration and interaction. ReCALL, 20, 271-289. https://doi.org/10.1017/S0958344008000335

Kukulska-Hulme, A., \& Traxler, J. (2005). Mobile learning: A handbook for educators and trainers. Psychology Press.

Lan, Y., Sung, Y., \& Chang, K. (2007). A mobile-device-supported peer-assisted learning system for collaborative early EFL reading. Language Learning \& Technology, 11(3), 130-151.

Lim Abdullah, M., Hussin, Z., Asra, B., \& Zakaria, A. R. (2013). MLearning scaffolding model for undergraduate English language learning: bridging formal and informal learning. TOJET: The Turkish Online Journal of Educational Technology, 12(2), 217-233.

Lu, M. (2008). Effectiveness of vocabulary learning via mobile phone. Journal of Computer Assisted Learning, 24(6), 515-525. https://doi.org/10.1111/j.1365-2729.2008.00289.x

Mayer, R. E. (2003). The promise of multimedia learning: using the same instructional design methods across different media. Learning and Instruction, 13(2), 125-139. https://doi.org/10.1016/S0959-4752(02)00016-6

Motallebzadeh, K., \& Ganjali, R. (2011). SMS: Tool for L2 vocabulary retention and reading comprehension ability. Journal of Language Teaching and Research, 2(5), 1111-1115. https://doi.org/10.4304/jltr.2.5.1111-1115

Nunan, D. (2015). Teaching English to speakers of other languages: An Introducation. NewYork: Routledge. https://doi.org/10.4324/9781315740553

Omer, A. M. (1997). The Study of Language: Phonetics. Alam Al-Kkutub, Egypt.

Palalas, A. (2011). Mobile-assisted language learning: Designing for your students. In S. Thouësny, \& L. Bradley (Eds.), Second language teaching and learning with technology: Views of emergent researchers. Dublin, Ireland: Research-publishing.net. https://doi.org/10.14705/rpnet.2011.000007

Shormani, M. Q., \& Alsohbani, Y. A. (2015). Phonological Transfer and Universal Grammar: Evidence from Arabic. Journal of Teaching and Teacher Education, 3(2). https://doi.org/10.12785/jtte/030203 


\section{Macrothink}

International Journal of Linguistics

ISSN 1948-5425

2019, Vol. 11, No. 6

Smith, B. (2001). Learner English: A teacher's guide to interference and other problems. Cambridge: Cambridge University Press.

Song, Y., \& Fox, R. (2008). Using PDA for undergraduate student incidental vocabulary testing. ReCALL, 20(3), 290-314. https://doi.org/10.1017/S0958344008000438

Thornton, P., \& Houser, C. (2005). Using mobile phones in English education in Japan. Journal of Computer Assisted Learning, 21(3), 217-228. http://dx.doi.org/10.1111/j.1365-2729.2005.00129.x

Valk, J.-H., Rashid, A. T., \& Elder, L. (2010). Using mobile phones to improve educational outcomes: An analysis of evidence from Asia. The International Review of Research in Open and Distributed Learning, 11(1), 117-140. https://doi.org/10.19173/irrodl.v11i1.794

Verma, A. (2014). Language in India, 14.

Wong, L. H., \& Looi, C. K. (2010). Vocabulary learning by mobile-assisted authentic content creation and social meaning-making: two case studies. Journal of Computer Assisted Learning, 26(5), 421-433. https://doi.org/10.1111/j.1365-2729.2010.00357.x

Yang, J. (2013). Mobile assisted language learning: review of the recent applications of emerging mobile technologies. English Language Teaching, 6(7), 19-25. https://doi.org/10.5539/elt.v6n7p19

\section{Copyrights}

Copyright for this article is retained by the author(s), with first publication rights granted to the journal.

This is an open-access article distributed under the terms and conditions of the Creative Commons Attribution license (http://creativecommons.org/licenses/by/4.0/) 